large, almost equalling the lobes, entire, and deeply grooved at the apex ; the maxillary palpi are porrected; the second joint is as long as the two following together; the fourth, in both the maxillary and labial ones, is triangular or slightly securiform, being obliquely truncated at the tip ; the thorax is elongated cordiform, truncated at the base; the back is elevated, divided down the middle by an impression; the commencement of the elevation forms two knobs at the base; the first tarsal joint is as long as the three following together.

[To be continued.]

XIX.-On a new species of Lardizabala, and on the Structure of the Seed in that genus. By John Mrers, F.R.S., F.L.S. \&c.

THE structure and affinities of the genera of the Lardizabalacea were scarcely known before the publication of the excellent monograph of M. Decaisne above twenty years ago, when the family was first established. Since that time little has been added to our knowledge of the order, except the interesting remarks of the authors of the 'Flora Indica,' who have described the Asiatic species, and have added a new and remarkable genus, which they have gracefully dedicated to the very eminent botanist before mentioned, the type being the Decaisnea insignis, a native of the Himalayas. M. Decaisne considered the family to be intermediate between Schizandracea and Berberidacea; and Prof. Lindley indicated its nearer affinity with the Menispermacea, at the head of which order it had long previously been placed as a distinct tribe by DeCandolle (Lardizabalea, Prodr. i. 95). In my memoir upon the Winteracea I have pointed out the intimate relationship existing between those two families.

It has been generally understood that the numerous ovules in the ovaries of the Lardizabalacee are scattered indiscriminately over the whole internal surface of the cell; but Drs. Hooker and Thomson show that in Decaisnea the ovules are confined to two regular lines of placentation, which they notice as an exceptional case, contrary to the condition which has been considered the chief characteristic of the order. In Lardizabala, a genus belonging exclusively to Chile, I have found that the ovules, in a similar manner, originate in six distinct parallel parietal placentæ, running from the base to the apex; and in the fruit, the seeds are likewise arranged in as many parietal lines. The distinguished botanists just mentioned also state that in Decaisnea the ripe fruit is filled with a cellular pulp, which is developed from the whole surface of the growing wall of the pericarp, thus forming a complete homogeneous mass, without leaving any 
cavity; and although this pulp firmly embraces the seeds, they observed no real adhesion except at the hilum, where there is a broad organic attachment between it and the external tunic: vessels originating from all parts of the surface of the pericarp ramify through the pulp, but do not meet in the axis of the fruit. A very similar development exists in Lardizabala, where the internal space of the fruit is filled with an edible gelatinous pulp: as the fruit dries, this pulp contracts into a pellicular covering that closely invests the black external tunic of the seeds, and within the substance of which numerous spiral vessels are distributed. It appears to me that this pulp is a secretion originating from the funicular point of attachment of each seed to the placenta, rather than an emanation from the entire surface of the cell; for round the hilar foramen in the seed of Lardizabala there exists a light-coloured annular cicatrix, which probably indicates the organic point of connexion of the pulpy envelope with that part of the external tunic, as described in the manner above-mentioned in Decaisnea, and which also forms the point of its junction with the placenta; for it will be shown that within a cavity of the external tunic there exists an expansion of the funicular mass, which evidently maintains that connexion through the hilar foramen before alluded to.

There are some peculiarities in the structure of the seed in Lardizabala that are worthy of attention. The seeds are ovoid, unequally gibbous, always more or less compressed, somewhat angular by the force of mutual pressure, and straighter upon the face next to the pericarp. The hilum, situated below the middle upon this face, consists of a rather small and somewhat oval aperture, which is filled with a fungous substance that becomes fleshy when moistened, and which is continuous with a mass of similar substance filling a large cavity within the tunic. This outer tunic, usually considered as the testa, is dark-coloured, thin, and somewhat chartaceous; and within it is found an inner coating consisting of two distinct adherent integuments. The albumen forming the enclosed nucleus is somewhat corneous, with a large hollow chamber on the side next the hilum; the two integuments last mentioned closely invest the inner surface of this chamber, as well as the external face of the albumen, but the outer shell is in no way inflected into the cavity. If we cut through a seed longitudinally across the line of the hilum, the albumen in this section appears of a gibbously hippocrepical form, with a large ovoid hollow space towards the centre; the two extremities of this horse-shoe are widely apart, the space in the form of a broad plate being filled with the fungous mass before mentioned. If we now cut through another seed in a transverse direction across 
the hilum, we find the hollow space deep and narrow, the albumen appearing in the shape of a more compressed horse-shoe, of which the crura are parallel; and in the vacuity is seen the same fungous substance in the form of a flattened plate, between which and the integuments lining the cavity there exists a very narrow space, showing that it is quite free from them in all parts, except at the periphery of the flattened plate, where it is attached to them by means of a very distinct cord or raphe filled with numerous spiral vessels. This raphe is observed both in the vertical and transverse sections, where it forms a broad hollow tube partaking of the nearly circular shape of the cavity, the inner surface of the tube being lined with a close web of white spiral vessels ; it is seen to originate at one of its extremities in the hilar foramen of the outer tunic, and after making nearly an entire circuit, it returns close to its starting-point, where it disappears in the chalaza of the inner integument, over the nidular place of the embryo. The embryo is very small, and is best seen in the longitudinal section, where it is found imbedded in the albumen in the extremity of the lower leg of the horse-shoe, or that nearest the hilar foramen of the outer tunic: it lies somewhat obliquely, with its radicle pointing outwards to a small external prominence of the albumen, and with the cotyledons directed towards the centre of the seed: the radicle is terete, short, obtuse, and of the length and breadth of the cotyledons, which are pointed and much compressed, its whole length being twice its own diameter, and about $\frac{1}{12}$ th of the total length of the seed.

On examining this evidence, we readily discern the nature of these several parts: the inference that the outer tunic, which has hitherto been denominated the testa, is of extraneous origin, and therefore of the nature of an arillus, is supported by four reasons:-1. Because it is not likely that the fungous plate, or large funicular expansion found within the cavity of the seed, could have found its way from the exterior into the hollow space through the small hilar foramen of the outer coating; on the contrary, it is more reasonable to conclude that this outer tunic must have been a subsequent formation after the ovule had become convoluted round that excentrically expanded support. 2. Because, had this tunic been the testa, that is to say, a simple development of the primine of the ovule, it would have exhibited some trace of its organic connexion with the other integuments, especially about the region of the chalaza, and would have partaken of the same form, and have been drawn along with them into the cavity. 3. Because this outer tunic is not only completely free from all contact with the raphe, but is far remote from and exterior to it, and therefore it must necessarily have been of a 
growth posterior to the curvature of the ovule. 4. Because the integument resulting from the growth of the primine is indicated beyond all doubt by the presence of the cord of the raphe within its substance: it is the more fleshy and exterior of the two integuments which immediately invest the albumen, following it in its excentric curvature, and adhering along the line of the raphe to the peripherical margin of the funicular plate. It would certainly be very incorrect to call this fleshy coating a testa : indeed it was for a similar reason that I proposed for the analogous coating in Clusia and Magnolia the term "arilline," in order to distinguish it from another more internal testaceous tunic, which is destitute of vessels of any kind. In fine, any one who will take the trouble to reflect on the consecutive changes that must take place in the development of the seed, and will keep his attention fixed upon the continuity and movement of the coats of the ovule during their excentric development and subsequent growth, must perceive how absolutely impossible it is that the external shell, circumstanced as we find it in this instance, can have derived its origin from the mere increment of the primine.

If we examine this external shell, we find it to be a thin, black, chartaceous or coriaceous entire crust, easily separable from the rest of the seed, owing to the deposition between it and the proper seminal integuments of a quantity of loose cellular tissue, mixed with coloured glands, which adhere to one as well as the other, and give to both a furfuraceous appearance. The coating which immediately invests the entire surface of the albumen in all its curvatures is composed of two distinct tunics, which, though adhering together, are separable. The outer one is soft, opake, and somewhat fleshy, containing numerous distinct cells, apparently filled with oily matter; it is much thicker around the region of the large hollow raphe: the inner integument is thin and membranaceous, and closely invests the albumen: both are also thickened around the chalazal point, which is situated in the lower part of the cavity near the site of the embryo.

It is said that in some of the Lardizabalacece (Akebia and Hollbollia) the ovules and seeds are partly imbedded in the fleshy walls of the pericarp; but in Lardizabala the reverse of this takes place; for here there is a protrusion of a part of the placenta, forming an expanded funicular support, about which the ovule bends itself, and becomes peltately convex around it,-the whole, as I have above shown, becoming subsequently enveloped by a complete arillus emanating probably from a growth of the placenta, or of its funicular extension. A metamorphosis of an analogous kind, that is to say, an excentric replicature of the ovule round 
its funicular support, occurs in the seeds of the tribes Heterocliniece and Anomospermea of the Menispermacee, only that in these cases there is no extraneous growth of any enveloping arillæform tunic, such as we find in Lardizabala : in the former cases, where the carpels are always unilocular and uniovular, and where the growth of the pericarp is constantly upon its dorsal face, while that of the ventral face is more or less stationary, it is easy to conceive how the ovule in its growth partakes of a similar kind of increment, and becomes moulded round the stationary fulcrum of its placentary attachment. But in Lardizabala, where the ovaries are multiovular, the partial protrusion of the placenta is not accompanied by an expansion of the walls of the pericarp. Something more analogous, however, occurs in the Myrsinacea, where the ovules often become moulded round the globular free placenta, and an arillus, in the shape of an inflated entire membranaceous sac, generated from the root of the placenta, encloses the seed together with its support*.

There is, however, a close analogy in the structure of the seed of Lardizabala with that of the Winteracea and Canellacea, if we except the circumstance of the deep cavity in the albumen, which does not occur in the two latter families. We find in all these cases a correlative, peculiar outer crustaceous shell; in the next place we see the same corresponding intervening layers of loosely aggregated oleiferous cells; then a similar fleshy tunic enclosing the cord of the raphe, and a still inner integument investing the albumen,-all bearing a striking analogy to the structure I have described in Illicium + . This structure shows the very close affinity that exists between the families last mentioned and the Lardizabalacer ; and in discussing the question of these affinities with other orders of the Polycarpica, I have already suggested the place that the Lardizabalacea should occupy, relatively to them, in the system $\neq$.

Ruiz and Pavon, who founded the genus Lardizabala, mention (Syst. i. 286) two species, both natives of Chile, the one with biternate oblong leaflets unequal at their base, the other with triternate ovate leaflets. DeCandolle (Syst. i. 512) amplified these brief characters by fuller details founded on his observation of dried specimens, adding at the same time the feature of the peculiar petiolar leaflets, which he termed bracts, and which he described as being round and cordate in the former case, and oblong in the other: he observed respecting the latter, that he found the leaves always biternate, as in the other species, not triternate, as mentioned by Ruiz and Pavon. L. 3-ternata

* I will at some future time describe the observations I have made on this singular structure.

+ Ante, p. 112. + Ante, p. 36 . 
was subsequently figured in Delessert's 'Icones,' i. 24. tab. 91, where the leaves are all divided biternately, and the leaflets are represented sometimes inequilateral at base, or partially lobed and mucronate, more or less regularly oblong or ovate, and subobtuse or acute. We find, moreover, in the same specimen the petiolar leaflets either cordate or rounded at base, orbicular or ovate, entire or denticulated. I cannot, therefore, perceive any permanent characters corresponding with the two species abovementioned, and certainly all the specimens I have seen are referable to one species. From the marked manner in which some of the leaflets in L. biternata are lobed, it is not unreasonable to suppose that the leaflets may sometimes become further subdivided; but that must be considered as a very exceptional feature. The specimens grown in this country, from which Sir Wm. Hooker made his drawing in Bot. Mag. tab. 4500, bear a rather different aspect, with the leaves somewhat modified in form and texture, from those of native specimens ; but that probably is the result of garden cultivation. The plant there described was brought from Concepcion, where it is stated to grow abundantly, and is no doubt identical with the specimens in our herbaria collected in the same neighbourhood.

The small leaflets at the base of the petiole have always been considered as bracts, but they appear to me to partake more of the character of stipulary leaves, for the following reasons:The peduncle, both of the male and female inflorescence, springs out of the middle of a bud-like verticil of small, erect, squamaceous, hairy bracts, similar in size and shape to those found at the base of the pedicels; this cluster of bracts grows ont of the middle of a conspicuous gland-like prominence, seated on the stem, a little above the petiole; and it is from the margin of this prominence that these leaflets emanate: this difference in the place of their origin shows that they should be considered as stipules rather than bracts. They occur both in the floriferous and barren axils, and therefore appear to have nothing to do with the inflorescence; the real bracts are always hairy, while these leaflets are smooth and veined, with a texture exactly resembling that of the leaves. I have occasionally seen a verticil of three of these leaflets at the base of a petiole.

During my residence at Concon, about twenty miles from Valparaiso, now thirty-five years ago, I found growing in its neighbourhood a species of Lardizabala in flower and in fruit, specimens of which I still possess. Concluding it to be a plant well known and described, I did not then bestow any particular attention upon it; and it was only by comparison with other specimens in different herbaria, after my return to England above twenty years afterwards, that I found it to differ essen- 
tially from $L$, biternata. I do not remember to have seen the male flower, at least I have no fragment or note of it: the flowers in my specimen are female, with sterile stamens, and they appear to me larger than in the other species. In the ordinary species the leaves, as before stated, are always biternate, or ternarily divided into nine leaflets, the lateral ones being inequilateral and sessile, generally very glabrous and polished; all the leaflets are more or less acuminated at base, and often at their summit, are at least twice as long as broad, triplinerved, the lateral nervures springing at some distance from the petiole, are thicker in texture, opake and somewhat coriaceous, while the primary and secondary petioles are longer in proportion. On the other hand, in my plant the leaves are simply trifoliate or divided into only three leaflets, as in Boquila; the leaflets are much larger in size, nearly as broad as long, conspicuously cordate and broadly truncated at base and obtuse at their summit, with a terminal mucro; they are all equilateral, quintuplinerved, the nervures originating at the base; they are very reticulated, much thinner in texture, more transparent, and are deeply sinuated on the margin, the nervures in each salient angle (of which there are six or eight on each side) terminating in a long cuspidate excurrent point: the lateral leaflets are both petiolulated; the main petiole and three petiolets are comparatively shorter, and they, as well as the nerves and veins beneath, are all pubescent. In another specimen gathered at the same spot, and accompanying the fruit, the leaves are much smaller, also simply 3 -foliate, the leaflets being more regularly obovate, slightly cordate, very opake, coriaceous, quite smooth, with thickened margins, which are almost entire or finely crenulated; in other respects it corresponds with the above-mentioned specimen, and is evidently taken from the end of a branch, as its stem is thin and very twining.

In $L$. biternata the stipulary leaves are large, orbicular, and sessile; in my plant only one remains, which is very small, linear, and attenuated at its base. The fruit is similar in size and shape to that of $L$. biternata, as figured in the Prodromus of the 'Flora Peruviana.' The plant I have described is known at Concon as the Coguil, being the same name as that given in Concepcion and the southern provinces of Chile to the plant of Ruiz and Pavon. 'Coguil' is properly the name of its edible fruit, 'Coguil-boqui' that of the plant, the word 'boqui' being applied alike to all scandent shrubs: the names attributed to it of 'Aguilboquil' and 'Guilboquil' by Dombey and La Perouse are certainly typical errors. In most botanical works, $L$. triternata is said to be a native of Peru, at Arauco; but this is a mistake common to most of the specimens collected in Chile by 
Dombey. Arauco is a province bordering on that of Concepcion, and separated from it by the river Biobio.

The following is offered as an amended character of the genus :-

Lardizabala, R. \& P.-Flores polygamo-dioici. Masc. Sepala 6, alternatim biseriata, carnosula, exteriora ovata, æstivatione valvata, interiora angustiora, spathulata, acuminata. Petala 6, biseriata, oblongo- vel lineari-lanceolata, acutiuscula, exteriora paullo latiora. Stamina 6; filamenta in tubum monadelphum coalita ; anthera extrorsæ, adnatæ, 2-loculares, connectivo breviter apiculatæ. Ovaria 3, rudimentaria, plus minusve attenuata. Fem. Sepala 6, biseriata, crassiuscula, campanulatim expansa, exteriora oblonga, versus basin attenuata, concava, interiora alternantia angustiora, imo spathulata. Petala 6, sepalis triplo breviora, biseriatim alterna, lineari-lanceolata, utrinque attenuata. Stamina 6, libera, hypogyna, gynophoro brevi inserta, petalis dimidio breviora; filamenta teretiuscula; antherce eorundem longitudine oblongæ, 2-loculares, connectivo apiculatæ, effœetæ. Ovaria $3 *$, teretia, cylindrica, medio extus gibbosa, unilocularia: ovula numerosissima, ad placentas 6 longitudinaliter, parietales prominentes horizontaliter affixa, campylotropa. Stylus brevis, obtusus, ovario continuus. Stigma sessile, glandulosum. Bacce 3, majusculæ, cylindricæ, torulosæ, stylo apiculatæ, polyspermæ. Semina subovata, gibba, compressa, fusca, in pulpam mucilagineam nidulantia, hilo infra medium marginali, parvulo, foramine pertuso: tunica externa testacea, fragilis; integumenta propria dupla, subadhærentia (exteriori subcarnoso raphigeri, interiori submembranaceo), albumen profundissime excavatum arcte vestientia, et circum podospermium magnum internum fungosum compresso-ovatum raphide tubuloso annulari cinctum configurata: albumen huic modo hippocrepice et profunde excavatum, acetabuliforme, magnum, carnosum : embryo marginem versus inferiorem acetabuli oblique inclusus, parvus, subteres, radicula cylindrica, infera, cotyledonibus compressis centripetis æquilonga et æquilata.

Frutices Chilenses scandentes, foliis alternis, ternatis vel biternatis, petiolatis, foliolis integris, vel sinuato-dentatis, coriaceis, nitidis, glabris, vel parce pubescentibus, petiolo refracto, imo stipulis foliaceis, sape rotundatis et majusculis donato ; pedunculo glabro e gemma squamiformi axillari orto, in masculis plurifloro, floribus breviter pedicellatis, racemosis, bracteolatis,

* Interdum 6 secundum DeCandolle, Syst. i. 512, sed dubia. 
bracteolis acutis, ciliolatis; in fomineis unifloro, flore majori ebracteato; floribus omnibus purpureis.

1. Lardizabala biternata, R. \& P. L. triternata, R. \& P. Prodr. Fl. Peruv. 143. tab. 37 ; Syst. i. 286 ; DC. Syst. i. 512 ; Prodr. i. 95 ; Delessert, Icones, i. tab.91 ; Decaisne, Archiv. Mus. i. 187. tab. 11; Hooker, Bot. Mag. tab. 4501.-Chile (Concepcion et Quillota).

2. Lardizabala sylvicola, nov.sp. ㅇ ; -ramulis volubilibus, striatis, glabris ; foliis 3-foliolatis, foliolis basi æqualibus, ample ovatis, late truncatis et subcordatis, obtusis, submembranaceis, margine cartilagineo, hinc inæqualiter sinuatis, angulis cuspidatis, 5-nerviis, valde reticulatis, omnibus petiolulatis, petiolulis lateralibus petiolo subæquilongis, intermedio 2-plo longiori, omnibus summo et imo incrassatis nervisque pilosulis, petiolo e basi subito refracto; stipulis axillaribus parvis, linearispathulatis, glabris, venosis, mucronato-denticulatis ; foliis terminalibus multo minoribus, glaberrimis, coriaceis, fere integris, margine cartilagineo crenulatis; floribus speciosis, violaceis, axillaribus, solitariis, pedunculo elongato, summo incrassato, e fasciculo bractearum orto, et paullo supra basin bractea unica donato, bracteis parvulis, acutis, margine ciliatis ; sepalis amplis in campanulam dispositis ; fructibus magnis, toruloso-cylindricis, edulibus.-Chile (apud Concon).

I found this plant at Concon, midway between Valparaiso and Quillota, in a wood that surrounds a small valley well sheltered by hills, called "Potrero del Peral." The short portion of the stem of the branchlet in my specimen is of the thickness of a goose-quill, somewhat flattened, and probably of a first year's growth, as it has a pithy medulla; the petiole, suddenly refracted backwards, is about 9 lines long, and much thickened at its base; the two lateral petiolets are 7 lines long, while the intermediate one measures 18 lines; the terminal leaflet is 3 inches long, and 3 inches wide at its broadest part, whence it is somewhat narrower towards the summit, which is round and emarginated, with a mucronate point; the lateral leaflets are $2 \frac{1}{2}$ inches long and $2 \frac{1}{4}$ inches broad; the stipules are minute, compared with those of the other species, and instead of being orbicular, cordate, and sessile, are linear and tapering to a small point at base; they are 3 lines long, barely a line broad, strongly reticulated, with a mucronately dentate border. The peduncle is $1 \frac{1}{2}$ inch long, somewhat slender below, and thickened towards its summit; about half an inch above its base it has a small, single, acute bract, which has ciliated margins, and it bears at its base a fascicle of similar bracts which rises out of a warty 
prominence situated just above the petiole, and it is upon the margin of this prominence that the stipules originate. The flower is expanded into a broad bell, with a reflected margin, which is 1 to $1 \frac{1}{4}$ inch in diameter; the three outer sepals are 10 lines long and 5 lines broad, somewhat obtuse at their summit, and narrower toward the base; the three inner sepals are 9 lines long, 3 lines broad, more acute at the summit, and still narrower at base. The six petals are shorter, almost linear, obtusely acuminate at the summit, attenuated at the base, and nearly equal in size, 5 lines long and 1 line broad in the widest part; the stamens are 3 lines long, the filaments being slender below, swelling above into a thick, fleshy, fusiform connective, in which the two sterile anther-cells are extrorsely imbedded, the connective terminating in a curved excurrent point. The three ovaries are 7 lines long, $1 \frac{1}{4}$ line in diameter, 1-locular, with six projecting parietal parallel placentæ, each bearing a number of minute, almost peltate ovules, supported upon a short prominent funicle, with a horizontal or sub-ascending direction. The fruit is cylindrical, torulose, six-grooved, apiculated by the persistent style, $1 \frac{3}{4}$ inch long, 1 inch in diameter; the pericarp is thin and coriaceous, extremely friable and of granular texture when dry; it is unilocular, and filled with a mucilaginous pulp, of a pleasant, sweet, and subacid taste, which dries into a thin epidermis that invests the seeds, and leaves a vacuity in the centre, without the vestige of any division. This is contrary to the statement of Ruiz and Pavon and other authors, who describe the fruit of L. biternata as being 6- or 8-locular. The seeds are very numerous, ovate, somewhat compressed, often subangular by mutual pressure, and are attached to the wall of the pericarp in a somewhat horizontal position by a small hilum; they are arranged in six very distinct series; they are about 5 lines long, 4 lines broad from the hilum to the more convex side, and 3 lines broad in the other transverse direction. Their structure has been already fully described*.

XX.-Characters and Descriptions of some new British SeaAnemones. By Philip H. Gosse, F.R.S.

\section{Fam. Sagartiadx.}

\section{Genus Phellia (mihi).}

Column pillar-like in expansion; margin tentaculate, without parapet or fosse. Surface smooth, pierced with loop-holes, partly

* A drawing of this species, with full details of the structure of its flower and seeds, is given in the 'Contributions to Botany,' plate 28. 


\section{$2 \mathrm{BHL}$ Biodiversity Heritage Library}

Miers, John. 1858. "XIX.-On a new species of Lardizabala, and on the structure of the seed in that genus." The Annals and magazine of natural history; zoology, botany, and geology 2, 183-192.

View This Item Online: https://www.biodiversitylibrary.org/item/19434

Permalink: https://www.biodiversitylibrary.org/partpdf/34516

\section{Holding Institution}

Natural History Museum Library, London

\section{Sponsored by}

Natural History Museum Library, London

\section{Copyright \& Reuse}

Copyright Status: Public domain. The BHL considers that this work is no longer under copyright protection.

This document was created from content at the Biodiversity Heritage Library, the world's largest open access digital library for biodiversity literature and archives. Visit BHL at https://www.biodiversitylibrary.org. 